\title{
Characterization of spatial heterogeneity of groundwater-stream water interactions using multiple depth streambed temperature measurements at the reach scale
}

\author{
C. Schmidt, M. Bayer-Raich, and M. Schirmer \\ Department of Hydrogeology, UFZ Centre for Environmental Research Leipzig-Halle in the Helmholtz Association, Leipzig, \\ Germany
}

Received: 8 May 2006 - Published in Hydrol. Earth Syst. Sci. Discuss.: 10 July 2006

Revised: 25 September 2006 - Accepted: 9 November 2006 - Published: 16 November 2006

\begin{abstract}
Streambed temperatures can be easily, accurately and inexpensively measured at many locations. To characterize patterns of groundwater-stream water interaction with a high spatial resolution, we measured 140 vertical streambed temperature profiles along a $220 \mathrm{~m}$ section of a small manmade stream. Groundwater temperature at a sufficient depth remains nearly constant while stream water temperatures vary seasonally and diurnally. In summer, streambed temperatures of groundwater discharge zones are relatively colder than downwelling zones of stream water. Assuming vertical flow in the streambed, the observed temperatures are correlated to the magnitude of water fluxes. The water fluxes are then estimated by applying a simple analytical solution of the heat conduction-advection equation to the observed vertical temperature profiles. The calculated water fluxes through the streambed ranged between $455 \mathrm{Lm}^{-2} \mathrm{~d}^{-1}$ of groundwater discharging to the stream and approximately $10 \mathrm{Lm}^{-2} \mathrm{~d}^{-1}$ of stream water entering the streambed. The investigated reach was dominated by groundwater discharge with two distinct high discharge locations accounting for $50 \%$ of the total flux on $20 \%$ of the reach length.
\end{abstract}

\section{Introduction}

Understanding and quantifying physical processes and ecological implications of groundwater surface water interaction is becoming an important subject in hydrogeological and river ecological studies. Stream water and groundwater can interact on a wide variety of scales down to heterogeneities within meters to centimetres (Brunke and Gonser, 1997; Woessner, 2000). Investigation of groundwater-stream water interactions (water fluxes through the streambed, hyporheic flowpaths, subsurface flow velocities and travel times) can

Correspondence to: C. Schmidt

(christian.schmidt@ufz.de) be classified according to "where-you-stand" as viewing interactions from the stream or the subsurface (Packman and Bencala, 2000). In studies where the point of view is from the stream, the hyporheic exchange is often the focus. Hyporheic exchange is the downwelling of stream water into shallow sediments and the return to the stream after a certain distance. These flow systems transport oxygenated stream water, nutrients and dissolved organic carbon into the hyporheic zone. This leads to increased mibrobial activity and significantly influences the nutrient and carbon cycling in stream systems. Nonetheless, the continuous hyporheic exchange also affects the downstream transport and fate of contaminants. Various studies incorporating different methods have analyzed hyporheic exchange. Deterministic approaches have shown that stream morphologic features can induce advective flow from the surface to the subsurface. Theory, laboratory experiments and field studies have investigated the influence of scale ( $\mathrm{cm}$ to tens of $\mathrm{m}$ ) and shape of bedforms and stream morphology on flowpathes, pore flow velocities and residence times of surface water in the hyporheic zone (Thibodeaux and Boyle, 1987; Elliott and Brooks, 1997a, b; Cardenas et al., 2003; Storey et al., 2003; Salehin et al., 2004; Saenger et al., 2005; Anderson et al., 2005; Gooseff, 2005). In general, an increased bed form wavelength and amplitude leads to increased depths and lengths of hyporheic flow paths for vertical features like pool and riffle sequences. The presence of meanders, secondary streams and streamsplits induce lateral near stream flow paths (Harvey and Bencala, 1993; Wroblicky et al., 1998; Kasahara and Wondzell, 2003). In this study, the interactions are viewed from the subsurface. As Storey et al. (2003) suggested, groundwater discharge can have a significant impact on the extent of the hyporheic zone and can affect the distribution of benthic and hyporheic fauna (Brunke and Gonser, 1997). In a modelling study Cardenas et al. (2006) underlined the importance of groundwater discharge for the flow systems and the biogeochemistry at the stream-groundwater interface. Temporal changes of

Published by Copernicus GmbH on behalf of the European Geosciences Union. 


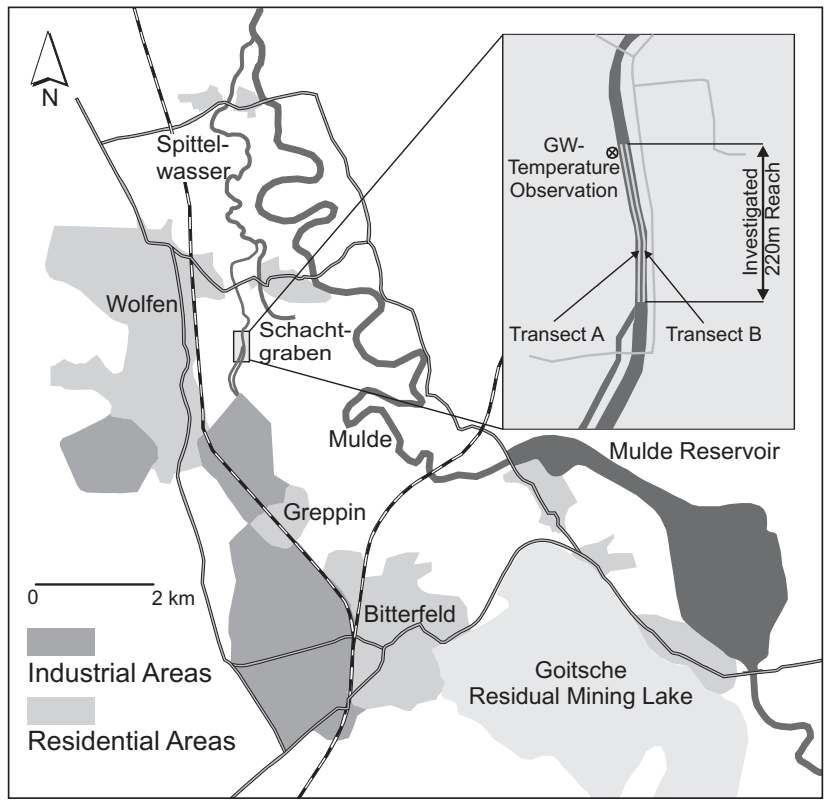

Fig. 1. Overview of the Bitterfeld-Wolfen region, showing the location of the Schachtgraben and illustrating the position of the investigated transects.

hydraulic gradients between an aquifer and a stream can alter the near stream groundwater flow field and the magnitude of both downwelling streamwater and upwelling groundwater (Wroblicky et al., 1998). Furthermore, it becomes essential to consider the spatial patterns and magnitude of groundwater discharge when the transport and the fate of contaminants from the aquifer to the stream has to be assessed (Conant et al., 2004; Conant, 2004). Independently from the point of view of the investigation, whether from the stream or the subsurface, it is crucial to consider the spatial distribution and the magnitude of groundwater discharge to a stream. In general, a variety of factors from the catchment scale to single bedforms are controlling the interactions of groundwater and stream water. As a result of different mechanisms, flow patterns within the streambed can vary on small spatial scales. Investigations at the stream reach scale which consider small-scale patterns of flow require a high density monitoring network. Due to instrumentation and measurement effort, such studies are often limited to a relatively small spatial extent (Baxter and Hauer, 2000). Thus there is a need for an inexpensive, quantitative method that has the capability to characterize the spatial heterogeneity of groundwater-stream water interactions. The characterization of spatial patterns of flow at the groundwater surface water interface requires a measurement concept that allows many measurements with high spatial resolution during a relatively short period of time. The horizontal and vertical temperature distribution in the streambed is a result of heat transport by the flowing water (advective heat flow) and by heat conduction through the sediment grains and the pore water (conductive heat flow) of the saturated sediments. While groundwater temperature remains nearly constant at the mean annual air temperature at a sufficient depth, stream water temperatures vary seasonally and diurnally. For example, in summer, streambed temperatures in groundwater discharge zones should be relatively colder than in stream water downwelling zones. The streambed temperature measurements coupled with an appropriate model can be used as a surrogate for head and hydraulic conductivity measurements (Anderson, 2005). Analytical solutions to solve the heat transport equation for water flux were developed in the 1960s (Suzuki, 1960; Stallman, 1965; Bredehoeft and Papadopolus, 1965). In recent years there have been several applications of temperature profiles for estimating magnitude and direction of water flow at the groundwater surface water interface (e.g., Bartolino and Niswonger, 1999; Constantz et al., 2003; Lapham, 1989; Silliman, 1995; Stonestrom and Constantz, 2003). Conant (2004) was the first who showed that streambed temperatures measured in a short period of time at many locations can be related to spatial variations of groundwater discharge. In contrast to the work of Conant (2004) who correlated mapped streambed temperatures with water fluxes estimated from 34 streambed piezometers and Darcy's law calculations, we used temperature measurements for direct estimation of water fluxes across the streambed. In this study, we show that streambed temperatures can be used to delineate patterns of groundwater discharge to a stream in fine detail on the scale of stream reaches with lengths of hundreds of meters. On the basis of the observed streambed temperature profiles, the vertical water fluxes through the streambed were quantified by applying a simple one dimensional analytical model of the heat advection-conduction equation.

\section{Study site}

The temperature measurements were carried out along a $220 \mathrm{~m}$ long reach of the Schachtgraben near the town of Wolfen (Fig. 1). The Schachtgraben is a man-made channel with a regular width between 2.5 and $3 \mathrm{~m}$. The mean annual stream discharge is $0.2 \mathrm{~m}^{3} \mathrm{~s}^{-1}$ and the gradient is $0.0008 \mathrm{~mm}^{-1}$. For the past one hundred years, Wolfen has been a major chemical industry site in Germany. In the second half of the 20th century the spectrum of products was extended to 5000 substances, including chlorinated solvents, pesticides and plastics (Walkow, 1996; Chemie AG Bitterfeld-Wolfen, 1993). The deposition of contaminated waste products in abandoned lignite pit mines nearby the production sites as well as inappropriate handling and transport of chemicals and war damages led to a large scale contamination $\left(25 \mathrm{~km}^{2}\right)$ of groundwater, soils, surface water and floodplain sediments (Heidrich et al., 2004). For decades, untreated process waste waters were discharged via the Schachtgraben and the Spittelwasser into the Mulde River 
which is a tributary of the Elbe River. The Schachtgraben channel is located in the Mulde River floodplain system. The channel cuts the floodplain sediments and is located in the sediments of the shallow Quaternary aquifer. The channel bed itself is constructed of a homogeneous coarse gravel layer of $0.4 \mathrm{~m}$ thickness. Groundwater levels in the adjacent unconfined aquifer are generally 0.1 to $0.2 \mathrm{~m}$ higher than the water level in the stream. The shallow aquifer is composed of Weichselian glacio-fluvial sandy gravels. Today streambed sediments and the groundwater in the adjacent aquifer and in the streambed sediments are contaminated with a wide range of substances but mainly with chlorinated benzenes and hexachlorocyclohexanes. Further downstream in the Spittelwasser floodplain, sediments were found to be contaminated with polychlorinated naphthalenes and dioxins (Brack et al., 2003; Bunge et al., 2003; Walkow, 2000). The investigated reach of the Schachtgraben and the Mulde River floodplain are the subject of additional studies concerning water flow as well as transport and fate of heavy metals and organic contaminants at the interface between groundwater and surface water.

\section{Field methods}

\subsection{Temperature measurements}

The streambed temperatures were measured along two longitudinal transects in a four day measuring programme from 30 August until 2 September 2005. The longitudinal transects were located at one third and two thirds of the total river width. The programme consisted of 140 measurements with 70 for each transect. Streambed temperatures were measured using a multilevel stainless steel temperature probe with attached data logger (TP 62, Umwelt Elektronik GmbH; Geislingen, Germany). The probe was temporarily inserted into the streambed to a depth of $0.5 \mathrm{~m}$. Along the probe five temperature sensors are placed in a way that the temperatures are simultaneously measured at $0.1 \mathrm{~m}, 0.15 \mathrm{~m}, 0.2 \mathrm{~m}, 0.3 \mathrm{~m}$ and $0.5 \mathrm{~m}$ below the streambed surface when the end of the probe is positioned in the depth of $0.5 \mathrm{~m}$ (Fig. 2). The measurements were generally taken with $3 \mathrm{~m}$ spacing but were refined between locations with high temperature differences. During the study, stream temperatures were measured hourly using a self containing Stowaway TidbiT -5 to $37^{\circ} \mathrm{C}$ range temperature logger (Onset Computer Coporation, Pocasset, Massachusetts). Groundwater temperature was observed hourly with temperature and pressure transducers placed directly into the aquifer with a vertical spacing of $1 \mathrm{~m}$ between depths below ground surface of $1 \mathrm{~m}$ to $5 \mathrm{~m}$ (Fig. 3). It was assumed that groundwater and surface water temperatures were spatially uniform and representative for the entire reach. Air temperature data was provided from a meterological station in Bitterfeld (Fig. 3).

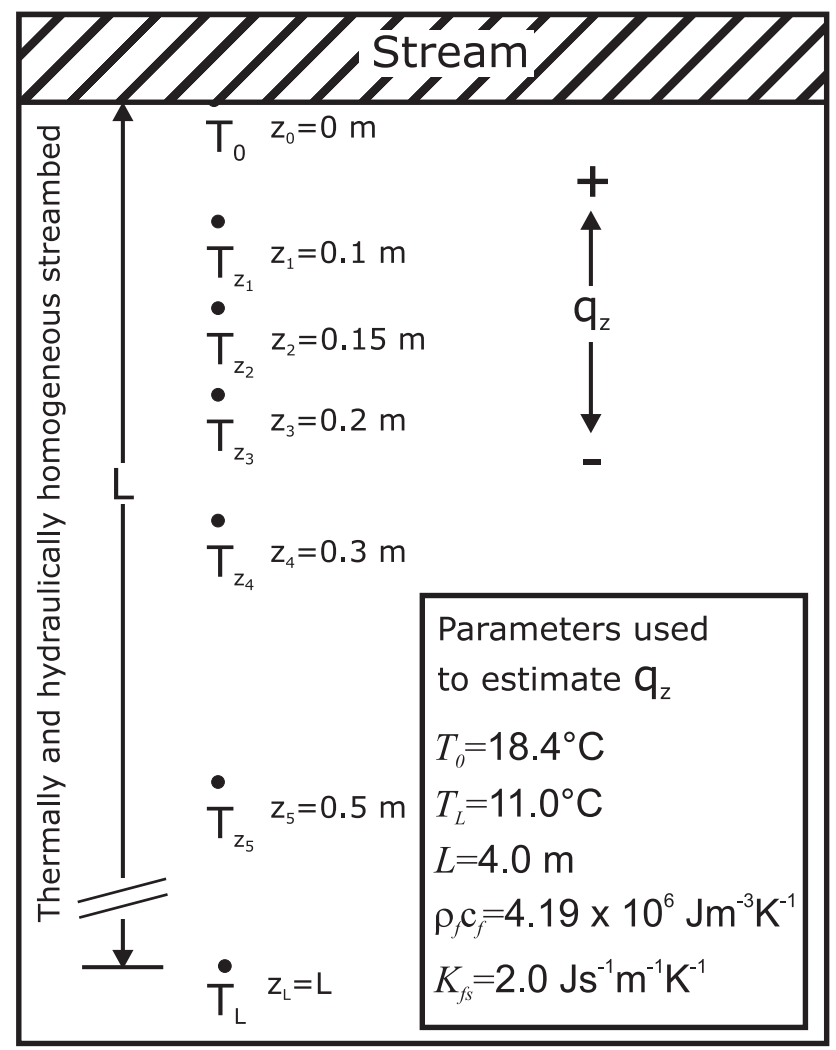

Fig. 2. Concept of vertical temperature profiles, boundary conditions and parameters used for the analytical model.

\subsection{Piezometer installation and slug testing}

To confirm the fluxes obtained from the streambed temperature profiles with an independent method, streambed piezometers were installed to gain information on hydraulic gradients and hydraulic conductivity. Locations were chosen according to high and low groundwater discharge zones indicated by the observed temperatures (high discharge locations: P2, P4, P5, P7; low discharge locations: P1, P3, P6). One pair of piezometers (P4, P5) was installed at a distinct groundwater discharge location at Transect A with $1 \mathrm{~m}$ spacing to obtain the small scale heterogeneities of streambed hydraulic properties and fluxes (Fig. 4).

The piezometers consist of $1.6 \mathrm{~m}$ long HDPE (high density polyethylene) pipes with $0.04 \mathrm{~m}$ outside diameter. The $0.2 \mathrm{~m}$ screened section of each piezometer was installed between 0.3 and $0.5 \mathrm{~m}$ below the streambed surface. The hydraulic head differences between the stream surface and the piezometers were estimated following the method of Baxter et al. (2003). To obtain the hydraulic head differences, an additional open pipe was attached outside the piezometer ("stilling well") to minimize the influence of turbulence on stream water elevation. The hydraulic head difference was measured using parallel chalked wires connected at the top. The chalked wires were inserted into a piezometer and the 


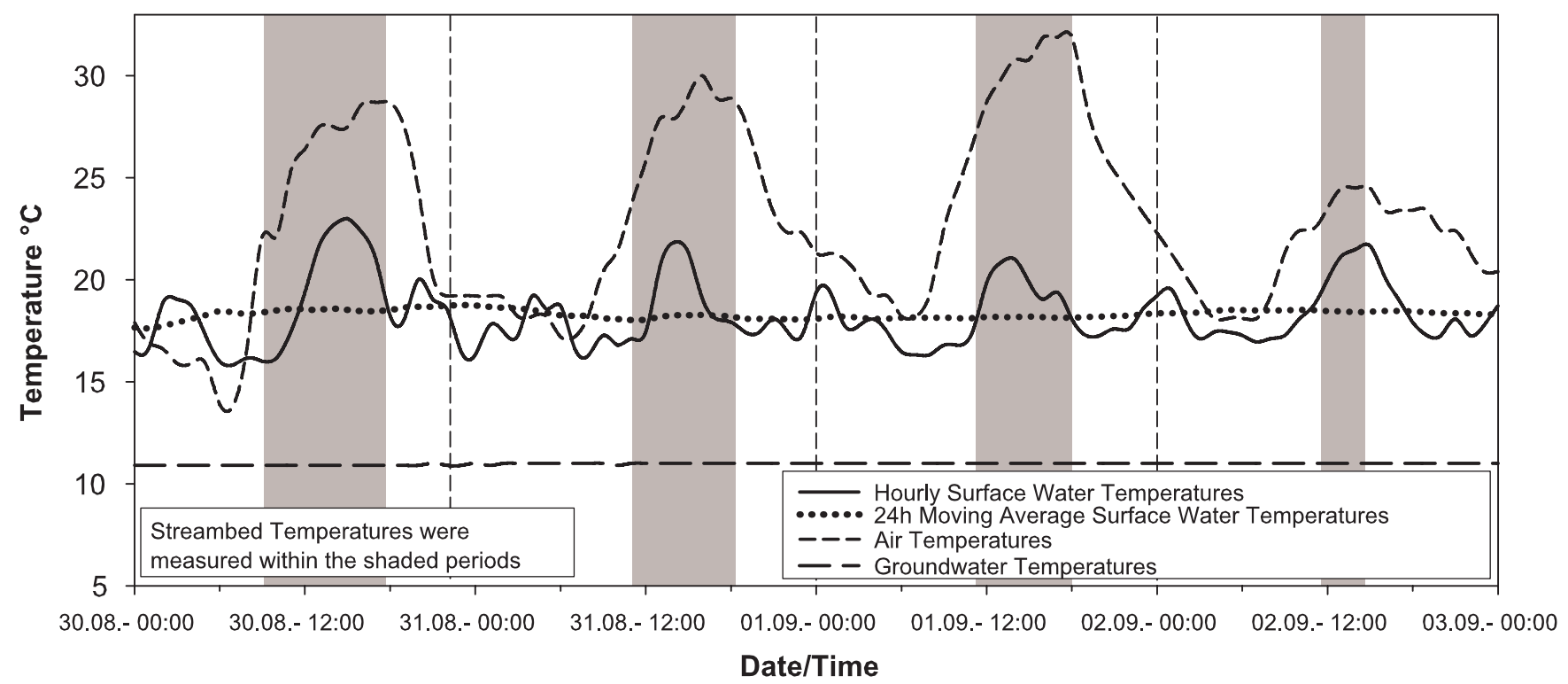

Fig. 3. Surface water, air and groundwater temperatures during the four day measurement programme in August/September 2005.

attached stilling well and after removal the distance between the water marks was measured.

Each piezometer was tested twice with a falling and rising head slug test. Rising head slug tests were performed by removing the water from the piezometer using an Eijkelkamp $12 \mathrm{~V}$ peristaltic pump (Eijkelkamp, Giesbeek, The Netherlands). Falling head slug tests were carried out by releasing water from an attached reservoir at the top of the piezometers. The rise and fall of the water level in the piezometers was observed with an "HT 575 Kompakt" pressure transducer (Hydrotechnik GmbH, Obergünzburg, Germany).

\section{Analytic procedure}

Streambed temperatures have a highly transient character due to seasonal and diurnal changes of stream water temperatures. It is essential for the concept of streambed temperature mapping that differences of temperature can be attributed to spatial differences of water fluxes and are not a result of temporal variations. Streambed temperatures measured at a sufficient depth below the influence of diurnal variations represent the quasi-steady-state conditions of streambed temperatures for the finite time of the mapping programme (Fig. 2).

With the assumption that water flow in the streambed is essentially vertical, the governing equation for onedimensional conductive and advective heat transport is:

$$
\frac{K_{f s}}{\rho c} \nabla^{2} T(z)-\frac{\rho_{f} c_{f}}{\rho c} \nabla \cdot\left(T(z) q_{z}\right)=\frac{\partial T}{\partial t}
$$

where $T_{z}\left[{ }^{\circ} \mathrm{C}\right]$ is the streambed temperature at depth $z ; t$ is time $[\mathrm{s}] ; q_{z}$ is the vertical Darcy velocity $\left[\mathrm{ms}^{-1}\right] ; \rho c$ is the volumetric heat capacity of the solid - fluid system which can be written as $\rho c=n \rho_{f} c_{f}+(1-n) \rho_{s} c_{s}$ where $\rho_{f} c_{f}$ is the volumetric heat capacity of the fluid, $\rho_{s} c_{s}$ is the volumetric heat capacity of the solids $\left[\mathrm{Jm}^{-3} \mathrm{~K}^{-1}\right]$ and $n$ is the porosity [-]. $K_{f s}$ is the thermal conductivity of the saturated sediment $\left[\mathrm{Js}^{-1} \mathrm{~m}^{-1} \mathrm{~K}^{-1}\right]$.

With boundary conditions $T=T_{0}$ for $z=0$, and a fixed temperature $T_{L}$ for $z=L$, where $L[\mathrm{~m}]$ is the vertical extent of the domain, the solution of Eq. (1) can be obtained as (Bredehoeft and Papadopolus, 1965):

$\frac{T(z)-T_{0}}{T_{L}-T_{0}}=\frac{\exp \left(\frac{q_{z} \rho_{f} c_{f}}{K_{f s}} z\right)-1}{\exp \left(\frac{q_{z} \rho_{f} c_{f}}{K_{f s}} L\right)-1}$

Equation (2) can be solved for $q_{z}$ for a given $L$. It is assumed that the vertical temperature distribution at different locations is only a function of $q_{z}$, i.e. other parameters on the righthand side of Eq. (2) are considered to be homogeneous for all observed temperature profiles. The objective function for obtaining $q_{z}$ is given with:

$\operatorname{Error}_{k}(L)=\sum_{j=1}^{5}\left[T_{j k}-\left(\frac{\exp \left(\frac{q_{z_{k}} \rho_{f} c_{f}}{K_{f s}} z_{j}\right)-1}{\exp \left(\frac{q_{z_{k}} \rho_{f} c_{f}}{K_{f s}} L\right)-1}\left(T_{L}-T_{0}\right)+T_{0}\right)\right]^{2}$

where $q_{z k}$ is the value of $q_{z}$ that minimizes Error ${ }_{k}(L)$ for a given $L$ at each temperature profile consisting of $j=5$ temperature observations.

It was tested if a change of $L$ has an influence on the estimated $q_{z}$ and the quality of the fit. The objective function to find one optimal $L$ for all observed temperature profiles implies the optimization of Error ${ }_{k}(L)$. We computed an optimal $q_{z k}$ at each profile $k$ for the overall $L$ ranging between 

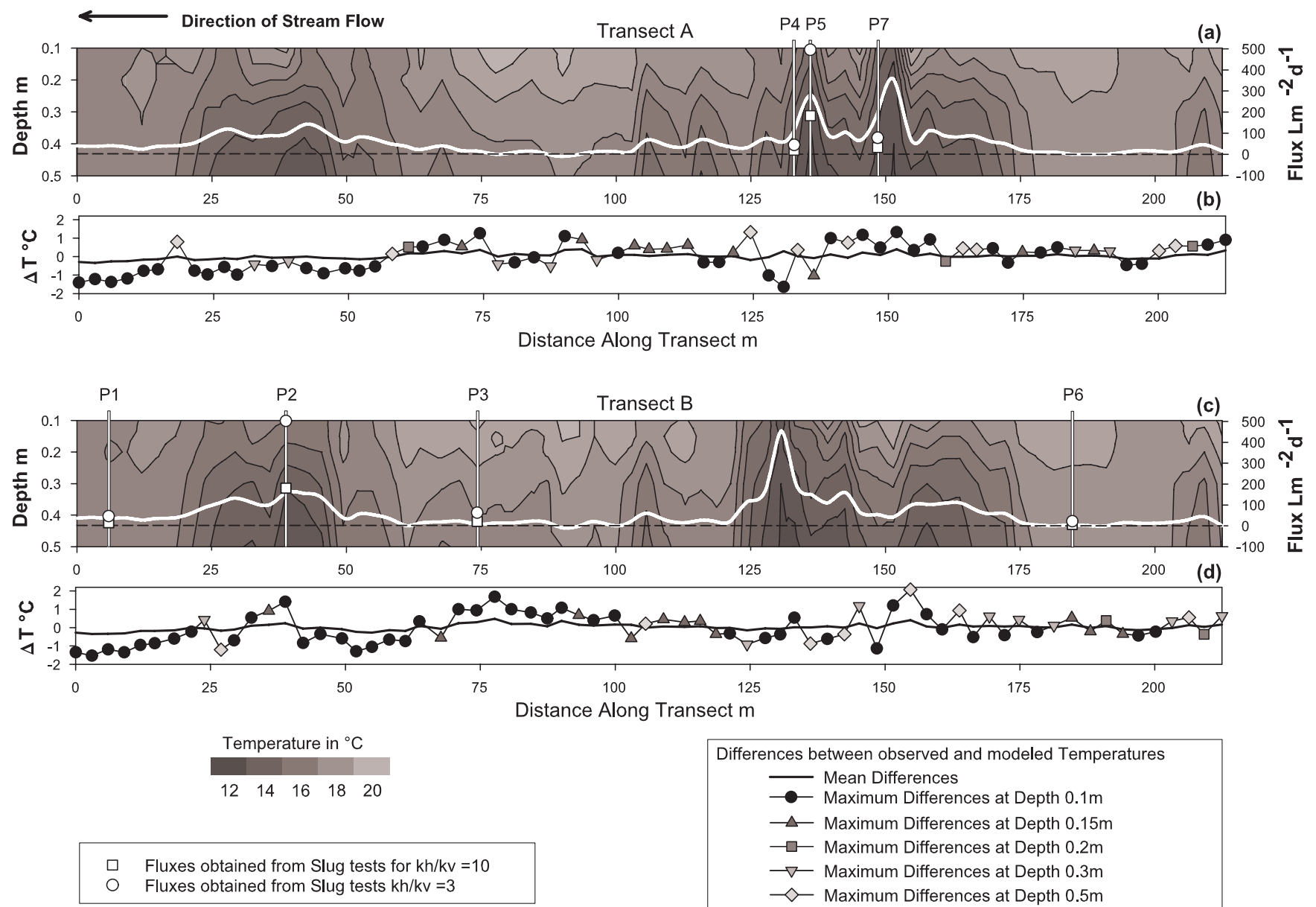

Fig. 4. Temperature distribution, temperature based fluxes, the locations of streambed piezometers, and the fluxes from Darcy's law calculations at each piezometer for different anisotropy ratios along Transects A (a) and B (c). Note the vertical exaggeration of the longitudinal profile by factor 50 .

Mean and maximum differences between observed and simulated temperatures for each temperature profile for Transects A (b) and B (d) The maximum difference is given with the respective depth. A bigger, coloured version of this figure can be found in the supplemental material: http://www.hydrol-earth-syst-sci.net/10/849/2006/hess-10-849-2006-supplement.pdf.

0.6 and $10 \mathrm{~m}$. For $k=140$ observed temperature profiles, the objective function is given with:

$f(L)=\sum_{k=1}^{140} \operatorname{Error}_{k}(L)$

Once the optimal $q_{z}$ for a chosen $L$ is obtained from Eq. (3), $q_{z}$ can be substituted into Eq. (2) to obtain a simulated streambed temperature distribution. To test the quality of fit between observed and simulated temperatures, the difference of temperatures $\Delta T\left[{ }^{\circ} \mathrm{C}\right]$ can be obtained from Eq. (5):

$\Delta T=T(z)-\frac{\exp \left(\frac{q_{z} \rho_{f} c_{f}}{K_{f s}} z\right)-1}{\exp \left(\frac{q_{z} \rho_{f} c_{f}}{K_{f s}} L\right)-1}\left(T_{L}-T_{0}\right)+T_{0}$

\section{Results and discussion}

\subsection{Stream water, groundwater and air temperatures}

During the field programme, the stream water temperatures showed variations with a low of 15.8 and a high of $23.0^{\circ} \mathrm{C}$ (Fig. 3). The dotted line in Fig. 3 illustrates the $24 \mathrm{~h}$ moving average of stream water temperatures. It varies only between $17.6^{\circ} \mathrm{C}$ and $18.6^{\circ} \mathrm{C}$ around the overall average of $18.4^{\circ} \mathrm{C}$ during the field campaign. This indicates that the temperature oscillations are of diurnal character. The temperature regime is characterized by anthropogenic influences which become apparent in temperature peaks in the early morning (Fig. 3). The temperature anomalies are caused by warm water regularly released from a reservoir for cooling sytems at the industrial area between Wolfen and Greppin (Fig. 1). Groundwater temperatures were observed in hourly intervals 


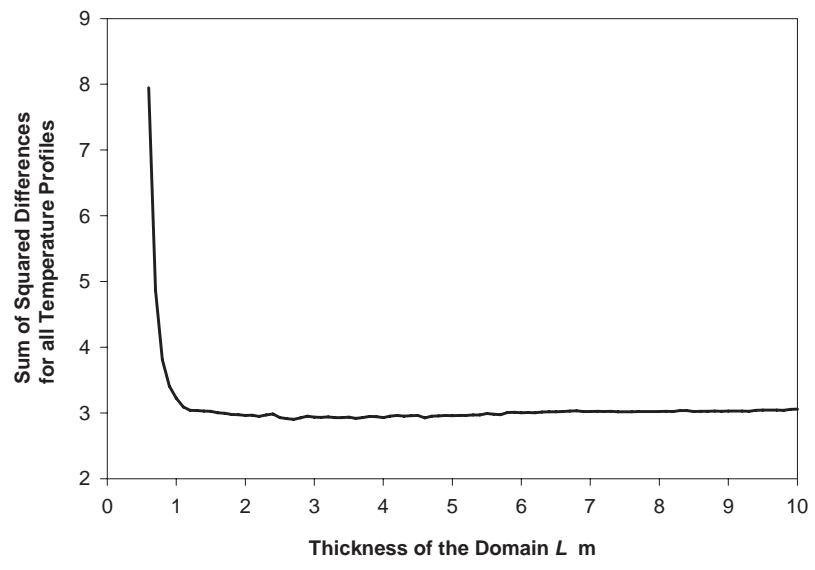

Fig. 5. Sum of squared errors of all temperature profiles vs. the thickness of the domain $L$. The results show that for the given parameter set, the quality of fit and the derived vertical fluxes are essentially constant for $L>1.0 \mathrm{~m}$.

at depths between 1 and $5 \mathrm{~m}$ below the streambed surface, adjacent to the stream (Fig. 1). At depths of 4 and $5 \mathrm{~m}$ the groundwater temperatures are $11^{\circ} \mathrm{C}$. Temperatures increase to $15^{\circ} \mathrm{C}$ at a depth of $1 \mathrm{~m}$ below the streambed surface. The groundwater temperatures were measured at a location close to a zone of relatively high streambed temperatures. Thus the shallow groundwater temperatures correspond well with the streambed temperatures being at $16.8^{\circ} \mathrm{C}$ at a depth of $0.5 \mathrm{~m}$. The coldest streambed temperatures are nearly identical to groundwater temperatures observed at a depth of $4 \mathrm{~m}$. The air temperatures were observed in a meteorological station in Bitterfeld $6.5 \mathrm{~km}$ south of the study site. During the field programme the air temperatures varied between 13.9 and $31.9^{\circ} \mathrm{C}$ with an average of $22.7^{\circ} \mathrm{C}$ (Fig. 3).

\subsection{Streambed temperatures}

The observed streambed temperatures varied spatially between 11.5 and $17.5^{\circ} \mathrm{C}$ at a depth of $0.5 \mathrm{~m}$ in the streambed. At the shallow depth of $0.1 \mathrm{~m}$, the temperatures showed a wider range and a higher minimum and maximum of 12.2 and $19.9^{\circ} \mathrm{C}$. In summer, groundwater discharge is indicated by relatively low streambed temperatures. Along the observed $220 \mathrm{~m}$ reach, two major groundwater discharge zones were identified. The first discharge zone is located between 20 and $50 \mathrm{~m}$ and the second between 125 and $170 \mathrm{~m}$ (Fig. 4). The discharge zones are characterized by streambed temperatures at $0.5 \mathrm{~m}$ being less than $15^{\circ} \mathrm{C}$. Within the second discharge zone, there are distinct locations showing temperatures less than $13^{\circ} \mathrm{C}$ at $0.5 \mathrm{~m}$ depth and even at $0.1 \mathrm{~m}$ depth, temperatures are less than $15^{\circ} \mathrm{C}$ (Fig. 4). These distinct locations of very low temperatures are restricted to a length of 3 to $5 \mathrm{~m}$. Both major discharge zones have a very similar spatial extent.

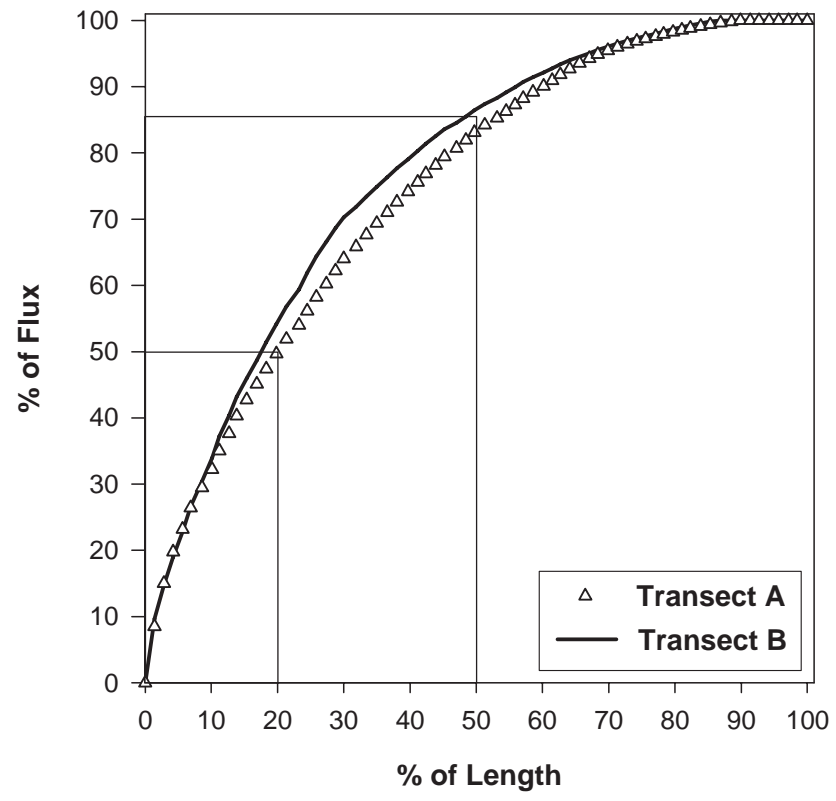

Fig. 6. Percentage of flux vs. percentage of length of the Transects A and B. Approximately $50 \%$ of the total flux occur on $20 \%$ of the total length.

Along both longitudinal transects, very similar patterns of streambed temperature are visible. Variations of streambed temperatures occur primarily along each reach while the differences between the eastern and western bank are of minor significance.

\subsection{Fluxes obtained from temperature profiles}

As temperature can be easily measured at hundreds of locations, the water fluxes in the streambed can be estimated with a high spatial resolution. The water fluxes were obtained at each location from Eq. (2) by minimizing the differences between observed and modelled temperature profiles (Eq. 3). At each temperature profile, $q_{z}$ was estimated for $L$ ranging from 0.6 to $10 \mathrm{~m}$. It was found that $q_{z}$ for $L$ larger than 1.0 was essentially independent from $L$ (Fig. 5). The resulting fluxes are not influenced by the depth at which $T_{L}$ is obtained as long as $T_{L}$ remains constant with the increasing depth. This is basically the case when upward flow from groundwater to surface water is present. The observed groundwater temperature at a depth of $4 \mathrm{~m}$ below the streambed surface was $11.0^{\circ} \mathrm{C}$ and was constant during the measuring campaign. Hence, the lower boundary condition $T_{L}$ was set to $11.0^{\circ} \mathrm{C}$. The upper boundary condition $T_{0}$ was set to $18.4^{\circ} \mathrm{C}$ which is the average stream water temperature of the fourday mapping period. Equation (2) requires the thermal conductivity $K_{f s}$ as an input parameter which was not measured within this study. However, the range of thermal conductivities of water saturated sediments is small thus $K_{f s}$ can be reliably estimated and was set to $2 \mathrm{Js}^{-1} \mathrm{~m}^{-1} \mathrm{~K}^{-1}$ (Stonestrom 


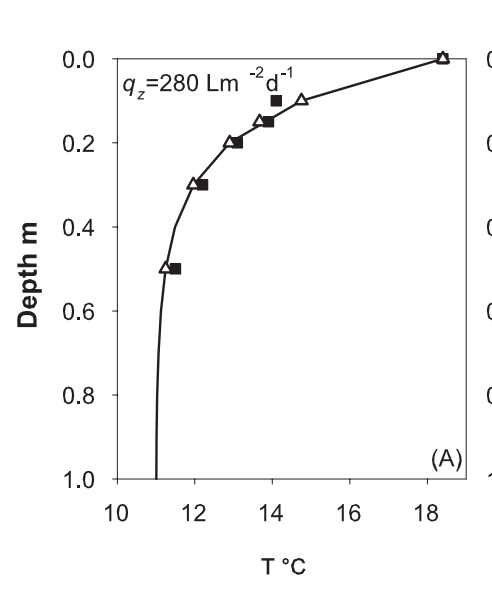

- Observed Streambed Temperatures

$\Delta \quad$ Simulated Streambed Temperatures
Fixed Surface Water Temperature at $18.4^{\circ} \mathrm{C}$
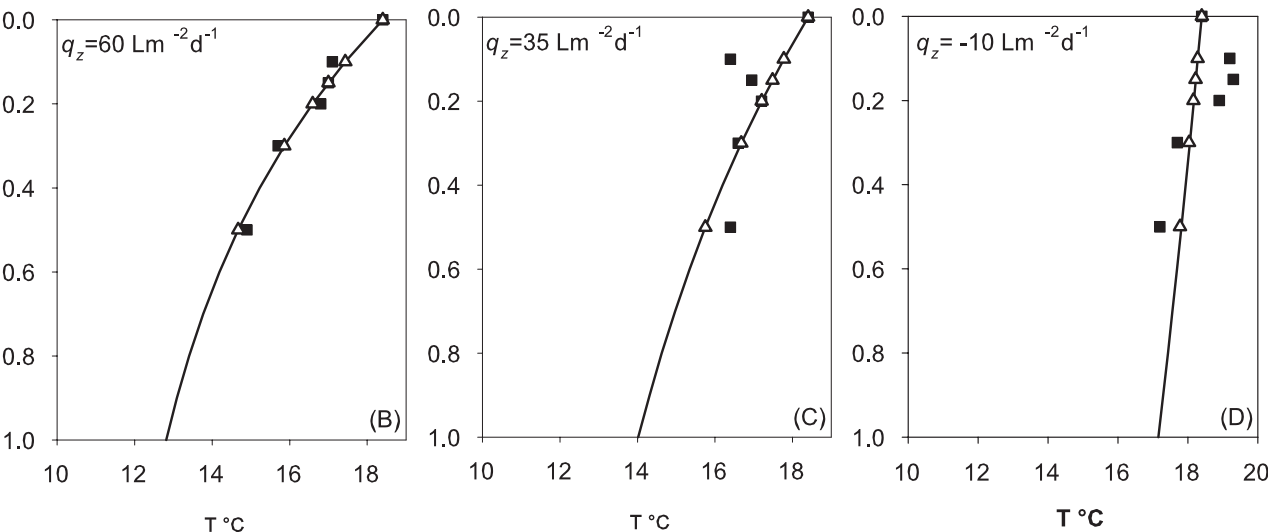

Fixed Groundwater Temperature at $11.0^{\circ} \mathrm{C}$ for $\mathrm{L}=4 \mathrm{~m}$

Fig. 7. Comparison of observed and simulated streambed temperatures for four example profiles. The illustrated profiles represent high (a), medium (b), low (c) groundwater discharges and low recharge conditions (d). The profiles are located proximal to the positions of streambed piezometers P5 (a), P4 (b), P1 (c) and P3 (d).

and Blasch, 2003). The parameter set used for estimating $q_{z}$ from the observed temperature profiles is summarized in Fig. 2.

The resulting water fluxes ranged between -10.0 and $455.0 \mathrm{Lm}^{-2} \mathrm{~d}^{-1}$ (Figs. 4a and c). The average groundwater discharge is $58.2 \mathrm{Lm}^{-2} \mathrm{~d}^{-1}$ and the average recharge is $2.3 \mathrm{Lm}^{-2} \mathrm{~d}^{-1}$. Figures $4 \mathrm{a}$ and $\mathrm{c}$ illustrate the spatial distribution of fluxes in relation to the length of the observed reach. Analogous to the temperatures, the flux distribution is very similar in the two longitudinal transects. Recharge occurs only along less than $1 \%$ of the reach. The zones with discharges higher than $100 \mathrm{Lm}^{-2} \mathrm{~d}^{-1}$ are present on $16 \%$ of the total length of Transect A and on 19\% of Transect B. Approximately $20 \%$ of the total length contributes $50 \%$ of the total discharge (Fig. 6). Around $85 \%$ of the total discharge occurred at $50 \%$ of the total length (Fig. 6) Only four profiles were observed to have discharges higher than $200 \mathrm{Lm}^{-2} \mathrm{~d}^{-1}$ which contribute about $10 \%$ to the total discharge (Figs. 4a and c). These relations as well as the order of magnitude of fluxes are comparable to those observed by Conant (2004). Spatially distinct high discharge zones were also observed in other studies but with higher maximum discharges (Baxter and Hauer, 2000; Conant, 2004). Yet the maximum discharges are more than 4 times higher than the average discharge. The reduced spread of fluxes compared to natural rivers can be explained with a reduced streambed heterogeneity in terms of morphologic features and hydraulic properties. According to the maximum fluxes the homogeneous streambed might lead to less significant preferential flowpaths and thus to lower maximum fluxes. The observed heterogeneities are likely to be also controlled by zones of preferential flow in the underlying aquifer. High- est discharges will occur at locations where permeable zones of the streambed are connected to high hydraulic conductivity zones in the aquifer (Conant, 2004). There are studies addressing the significant role of aquifer heterogeneity for the magnitude and spatial distribution of flow from the stream to the subsurface in loosing stream reaches (Fleckenstein et al., 2006; Bruen and Osman, 2004). As the work of Conant (2004) and Conant et al. (2004) indicates aquifer heterogeneity will have an analogous effect in gaining streams but it has not been examined in a theoretical study to date.

Recharge occurs only at few locations and at low flow rates (up to $10 \mathrm{Lm}^{-2} \mathrm{~d}^{-1}$ ). Admittedly, in these cases the fit of the analytical solution to the observed streambed temperatures is rather poor (Fig. 7d). Thus the estimated recharges are associated with high uncertainty, in particular with regard to the observed vertical hydraulic gradients in the streambed piezometers and the water table elevation adjacent to the Schachtgraben channel which indicate a gaining reach. Moreover, Storey et al. (2003) reported that a streambed hydraulic conductivity below $10^{-4} \mathrm{~ms}^{-1}$ will result in a restricted topographically induced downwelling of water. Downward flow can occur at pool and riffle structures and at smaller spatial scales at streambed ripples (Thibodeaux and Boyle, 1987) and obstructions (Hutchinson and Webster, 1998). Because of the artificial origin of the homogeneous gravel streambed, natural pool and riffle sequences are assumed not to be present at the Schachtgraben. Consequently, the combination of a streambed with no apparent geomorphological heterogeneity and low streambed hydraulic conductivities leads to the observed low recharge fluxes. It is likely that if downwelling of stream water occurs it will be mainly due to streambed roughness induced by the single 
gravel grains. Since hyporheic flowpaths are related to the vertical extent of the streambed morphologic features, hyporheic flow in the Schachtgraben can only occur in the upper few centimetres of the streambed. In conclusion, the interactions of stream and groundwater at this site are dominated by groundwater discharge at distinct locations. Morphological features like pool and riffle structures or obstructions were not apparent at the investigated reach. Because of the artificial origin the streambed appeared to be relatively homogeneous in its hydraulic properties. Therefore, it is likely that the observed spatial heterogeneities of groundwater discharge are not solely controlled by the streambed. High permeable zones of the underlying aquifer connected to the streambed are expected to significantly influence the observed discharge patterns.

5.4 Differences between observed and simulated temperatures

The mean difference between all observed and simulated temperatures is $0.023^{\circ} \mathrm{C}$ at Transect $\mathrm{A}$ and $0.028^{\circ} \mathrm{C}$ at Transect $\mathrm{B}$. The highest calculated difference at Transect $\mathrm{A}$ was $2.1^{\circ} \mathrm{C}$, located at a depth of $0.1 \mathrm{~m}$ and at was $-1.6^{\circ} \mathrm{C}$ Transect $\mathrm{B}$ also at a depth of $0.1 \mathrm{~m}$ (Figs. $4 \mathrm{~b}$ and d).

At both transects, although the observed patterns of temperatures were very similar, the highest differences between simulated and observed temperatures occured at different locations. The differences are clearly related to certain depths but seemed to be randomly distributed along the transects (Fig. 4). At 82 out of 140 temperature profiles (58.6\%), the maximum difference between observed and simulated temperatures occurs at $0.1 \mathrm{~m}$ depth. At the other depths of $0.15 \mathrm{~m}, 0.2 \mathrm{~m}, 0.3 \mathrm{~m}$ and $0.5 \mathrm{~m}$ the maximum differences are similarly distributed, respectively $13.6 \%, 5.9 \%, 11.4 \%$ and $11.4 \%$. This distribution of differences indicates that there is an influence of diurnal stream water temperature oscillations at the shallow depth of $0.1 \mathrm{~m}$, disturbing the quasisteady-state profile. As well it is possible that shallow, nonvertical hyporheic flow paths could have influenced the upper $0.1 \mathrm{~m}$ of the streambed. Figure 7 illustrates examples of simulated temperature profiles after $q_{z}$ was obtained from observed temperatures using Eq. (3) and the related observed temperatures at $T(z)$. A recalculation of fluxes excluding the temperature measurements at a depth of $0.1 \mathrm{~m}$ showed that there is no significant influence for low and medium fluxes. At high flux locations the resulting fluxes decrease when the shallowest measurement is excluded. For example the calculated maximum flux is reduced from 455 to $325 \mathrm{Lm}^{-2} \mathrm{~d}^{-1}$ without the temperature at $0.1 \mathrm{~m}$ depth. Although there are indications that temperatures within $0.1 \mathrm{~m}$ are influenced by diurnal temperature oscillations in the surface water, there is no evidence for an increased uncertainty in the resulting fluxes. In particular for groundwater discharge, where streambed temperatures change from groundwater temperature to stream water temperature in the upper few centimetres of the streambed, it is essential to have an observation point at a shallow depth.

\subsection{Verification of flux calculations with piezometer data}

A total number of 7 streambed piezometers was installed and tested to confirm the magnitude of water fluxes obtained from the temperature profiles (Figs. 4a and c). The observed head differences $\Delta h$ between the streambed and the aquifer indicated an upward flow direction at all streambed piezometers. The maximum $\Delta h$ occurred at piezometer $\mathrm{P} 2$ with $0.118 \mathrm{~m}$, the minimum $\Delta h$ at piezometer $\mathrm{P} 7$ with $0.017 \mathrm{~m}$. The vertical hydraulic gradient was obtained by dividing $\Delta h$ with $\Delta l$ which is the length between the centre of the piezometer screen and the top of the streambed. All piezometers were installed at the same depth in the streambed and thus $\Delta l$ is $0.4 \mathrm{~m}$ at all piezometer locations. The resulting vertical hydraulic gradients are between 0.043 and 0.295 .

Streambed hydraulic conductivities were estimated from rising and falling head slug tests using the Hvorslev (1951) case G, basic time lag equation. Horizontal hydraulic conductivities $K_{h}$ varied within a relatively small range of one order of magnitude between $1.39 \times 10^{-4}$ and $1.26 \times 10^{-5} \mathrm{~ms}^{-1}$. As the cobbely streambed makes it impossible to install permeameters to obtain the vertical hydraulic conductivity $K_{v}$ in the field, the anisotropy ratio has to be estimated. Freeze and Cherry (1979) gave an anisotropy ratio of core samples $K_{h} / K_{v}$ between 3 and 10. The resulting hydraulic conductivities are within the range given by Calver (2001) and lower than the vertical hydraulic conductivities observed by Chen (2004).

Employing both an anisotropy ratio of 3 and 10, the resulting fluxes based on the piezometer data are within one order of magnitude of the fluxes obtained from the temperature data (Table 1 and Fig. 5). In general, the fluxes obtained from Eq. (2) correspond reasonably well with the fluxes obtained from Darcy's law calculations. At piezometer locations P3 and P5, fluxes calculated with an anisotropy ratio of 3 overestimate the temperature based fluxes while fluxes based on an anisotropy ratio of 10 underestimate them.

\subsection{Applicability and limitations}

Using streambed temperatures to quantify groundwaterstream water interactions is limited to locations and time periods where groundwater and stream water have sufficient temperature differences which is normally the case in summer or winter. The best conditions to perform the temperature measurements are given if during the measurements the surface water temperatures vary solely diurnal (no ambient trend), the surface water temperature maximum (winter) or minimum (summer) does not reach groundwater temperature. In this approach the conceptualization of water fluxes in the streambed is based on the assumption of vertical flow. In streams with intense non-vertical hyporheic flow in the 
Table 1. Hydraulic conductivities, hydraulic gradients and vertical fluxes obtained from slug-tests using streambed piezometers.

\begin{tabular}{lllllll}
\hline \multirow{2}{*}{ Name } & $\begin{array}{l}\text { Horizontal } \\
\text { Hydraulic } \\
\text { Conductivity } \\
K_{h} \mathrm{~ms}^{-1}\end{array}$ & $\begin{array}{l}\text { Vertical } \\
\text { Hydraulic } \\
\text { Gradient }\end{array}$ & $\begin{array}{l}\text { Vertical Hydraulic } \\
\text { Conductivity } \\
K_{v} \mathrm{~ms}^{-1} \text { for } \\
K_{h} / K_{v}=3\end{array}$ & $\begin{array}{l}\text { Vertical Flux } \\
q_{z} \mathrm{Lm}^{-2} \mathrm{~d}^{-1} \\
\text { for } K_{h} / K_{v}=3\end{array}$ & $\begin{array}{l}\text { Vertical Hydraulic } \\
\text { Conductivity } \\
K_{v} \mathrm{~ms}-1 \\
\text { for } K_{h} / K_{v}=10\end{array}$ & $\begin{array}{l}\text { Vertical Flux } \\
q_{z} \mathrm{Lm}^{-2} \mathrm{~d}^{-1} \\
\text { for } K_{h} / K_{v}=10\end{array}$ \\
\hline P1 & $2.38 \mathrm{E}-05$ & 0.070 & $7.92 \mathrm{E}-06$ & 47.9 & $2.88 \mathrm{E}-06$ & 17.4 \\
P2 & $5.82 \mathrm{E}-05$ & 0.295 & $1.94 \mathrm{E}-05$ & 494.6 & $7.04 \mathrm{E}-06$ & 179.5 \\
P3 & $1.99 \mathrm{E}-05$ & 0.113 & $6.63 \mathrm{E}-06$ & 64.4 & $2.41 \mathrm{E}-06$ & 23.4 \\
P4 & $1.20 \mathrm{E}-05$ & 0.113 & $4.01 \mathrm{E}-06$ & 39.0 & $1.46 \mathrm{E}-06$ & 14.1 \\
P5 & 6.87 E-05 & 0.245 & $2.29 \mathrm{E}-05$ & 484.6 & $8.31 \mathrm{E}-06$ & 175.9 \\
P6 & $1.36 \mathrm{E}-05$ & 0.063 & $4.52 \mathrm{E}-06$ & 24.4 & $1.64 \mathrm{E}-06$ & 8.9 \\
P7 & $5.82 \mathrm{E}-05$ & 0.043 & $1.94 \mathrm{E}-05$ & 71.9 & $7.04 \mathrm{E}-06$ & 26.1 \\
\hline
\end{tabular}

streambed, the presented approach may not be valid. At locations with a very high groundwater discharge, streambed temperatures can be nearly equal to groundwater temperature. If the flux is doubled or tripled, the temperature will remain the same (Conant, 2004). Lapham (1989) states if upward fluxes exceed $\left.305 \mathrm{Lm}^{-2} \mathrm{~d}^{-1}\right)(1 \mathrm{ft} / \mathrm{d})$ the temperature in the streambed would be equal the groundwater temperature and remain unaffected by fluctuations in stream temperature. We observed higher magnitudes of fluxes (up to $\left.455 \mathrm{Lm}^{-2} \mathrm{~d}^{-1}\right)$ ). The constraints depend strongly on the depths in which the measurements were taken. We observed in depths of $0.3 \mathrm{~m}$ and $0.5 \mathrm{~m}$ below the streambed surface that streambed temperatures can be nearly equal to groundwater temperatures. This never occurred in depth of $0.15 \mathrm{~m}$ or $0.1 \mathrm{~m}$. With a decreased measurement depth the magnitude of fluxes that can be accurately quantified can be increased. A similar behaviour occurs for high downward fluxes. In these cases, the observed streambed temperatures can be essentially equal to stream water temperatures. At these particular locations the calculated fluxes would represent the minimum flux but the true fluxes could be higher. Streambed temperatures cannot be used for a reliable quantification of the water fluxes at these locations. The presented method focuses on spatial patterns of groundwater-stream water interactions. Temporal changes of flow conditions in the streambed are beyond the scope of this approach.

\section{Conclusions}

We measured streambed temperatures at depths of $0.1 \mathrm{~m}$, $0.15 \mathrm{~m}, 0.2 \mathrm{~m}, 0.3 \mathrm{~m}$ and $0.5 \mathrm{~m}$ along a $220 \mathrm{~m}$ long reach of an artificial stream. Based on the observed temperatures, the vertical water fluxes were estimated by applying a one-dimensional analytical solution of the heat-advectiondiffusion-equation. As temperature can be inexpensively and easily measured, hundreds of measurements can be taken to draw a high resolution picture of groundwater-stream water interactions on the scale of stream reaches. The simple con- cept of relating streambed temperatures to spatial differences of vertical water flux might be subject to several limitations and uncertainties but provides a reasonable agreement between simulated and observed temperatures. Furthermore, the independent results of Darcy's law calculations based on streambed piezometer data confirmed the fluxes derived from the temperature profiles.

Although the artificial streambed at our study site appears to be relatively homogeneous in comparison to natural streams, a considerable spatial heterogeneity of groundwater-stream water interactions was observed. Only $20 \%$ of the total length contributes to $50 \%$ of the total groundwater discharge to the stream. A significant downwelling of streamwater was not observed.

Investigations aiming at characterization of groundwater surface water interaction can benefit from using multiple methods and techniques. The quantification of water fluxes through the streambed is of particular importance when mass fluxes of solutes and contaminants at the interface between groundwater and surface water are of interest. In cases of groundwater contamination, high groundwater discharge locations will contribute a great extent to the contaminant input into the stream. It is essential that these locations are identified precisely on river segments to $1 \mathrm{~km}$ length to assess, for instance, the potential impact of large scale groundwater contamination on the stream. We consider streambed temperature measurements to be a useful tool to gain insight into the spatial heterogeneity of fluxes along a stream reach. Because of its proven effectiveness, this method can be applied on a field site before other methods are used for choosing the locations of additional instrumentation.

Acknowledgements. We thank R. Krieg for his efforts during the field work and E. Kalbus for critical and fruitful discussions. This work was supported by the European Union FP6 Integrated Project AquaTerra (Project no. 505428) under the thematic priority "Sustainable Development, Global Change and Ecosystems".

Edited by: K. Bishop 


\section{References}

Anderson, J. K., Wondzell, S. M., Gooseff, M. N., and Haggerty, R.: Patterns in stream longitudinal profiles and implications for hyporheic exchange flow at the H. J. Andrews Experimental Forest, Oregon, USA, Hydrol. Processes, 19(15), 2931-2949, 2005.

Anderson, M. P.: Heat as a ground water tracer, Ground Water, 43(6), 951-968, 2005.

Bartolino, J. R. and Niswonger, R. G.: Numerical simulation of vertical ground-water flux of the Rio Grande from ground-water temperature profiles, central New Mexico, 1999.

Baxter, C., Hauer, F. R., and Woessner, W. W.: Measuring groundwater-stream water exchange: New techniques for installing minipiezometers and estimating hydraulic conductivity, Transactions of the American Fisheries Society, 132(3), 493502, 2003.

Baxter, C. V. and Hauer, F. R.: Geomorphology, hyporheic exchange, and selection of spawning habitat by bull trout (Salvelinus confluentus), Can. J. Fisheries and Aquatic Sci., 57(7), 1470 1481, 2000.

Brack, W., Kind, T., Schrader, S., Möder, M., and Schüürmann, G.: Polychlorinated naphthalenes in sediments from the industrial region of Bitterfeld, Environ. Pollut., 121(1), 81-85, 2003.

Bredehoeft, J. D. and Papadopolus, I. S.: Rates of Vertical Groundwater Movement Estimated from the Earth's Thermal Profile, Water Resour. Res., 1(2), 325-328, 1965.

Bruen, M. P. and Osman, Y. Z.: Sensitivity of stream-aquifer seepage to spatial variability of the saturated hydraulic conductivity of the aquifer, J. Hydrol., 293(1-4), 289-302, 2004.

Brunke, M. and Gonser, T.: The ecological significance of exchange processes between rivers and groundwater, Freshwater Biology, 37(1), 1-33, 1997.

Bunge, M., Adrian, L., Kraus, A., Opel, M., Lorenz, W. G., Andreesen, J. R., Gorisch, H., and Lechner, U.: Reductive dehalogenation of chlorinated dioxins by an anaerobic bacterium, Nature, 421(6921), 357-360, 2003.

Calver, A.: Riverbed permeabilities: Information from pooled data, Ground Water, 39(4), 546-553, 2001.

Cardenas, M. B., Wilson, J. L., and Zlotnik, V. A.: Impact of heterogeneity, bed forms, and stream curvature on subchannel hyporheic exchange, Water Resour. Res., 40(8), doi:10.1029/2004WR003008, 2004.

Cardenas, M. B. and Wilson, J. L.: The influence of ambient groundwater discharge on exchange zones induced by currentbedform interactions, J. Hydrol., 331(1-2), 103-109, 2006.

Chemie AG Bitterfeld-Wolfen: Bitterfelder Chronik, Bitterfeld, 1993.

Chen, X.: Streambed hydraulic conductivity for rivers in southcentral Nebraska, J. Amer. Water Resour. Assoc., 40(3), 561573, 2004.

Conant, B.: Delineating and quantifying ground water discharge zones using streambed temperatures, Ground Water, 42(2), 243 257,2004

Conant, B., Cherry, J. A., and Gillham, R. W.: A PCE groundwater plume discharging to a river: influence of the streambed and near-river zone on contaminant distributions, J. Contam. Hydrol., 73(1-4), 249-279, 2004.

Constantz, J., Tyler, S. W., and Kwicklis, E.: Temperature-Profile Methods for Estimating Percolation Rates in Arid Environments, Vadose Zone J., 2(1), 12-24, 2003.
Elliott, A. H. and Brooks, N. H.: Transfer of nonsorbing solutes to a streambed with bed forms: Laboratory experiments, Water Resour. Res., 33(1), 137-151, 1997.

Elliott, A. H. and Brooks, N. H.: Transfer of nonsorbing solutes to a streambed with bed forms: Theory, Water Resour. Res., 33(1), 123-136, 1997.

Fleckenstein, J. H.: River-Aquifer Interactions, Geologic Heterogeneity, and Low-Flow Management, Ground Water, 44(6), 837852, 2006.

Freeze, R. A. and Cherry, J. A.: Groundwater, Prentice-Hall, New Jersey, 1979.

Gooseff, M. N., Anderson, J. K., Wondzell, S. M., LaNier, J., and Haggerty, R.: A modelling study of hyporheic exchange pattern and the sequence, size, and spacing of stream bedforms in mountain stream networks, Oregon, USA, Hydrol. Processes, 19(15), 2915-2929, 2005.

Harvey, J. W. and Bencala, K. E.: The effect of streambed topography on surface-subsurface water exchange in mountain catchments, Water Resour. Res., 29(1), 89-98, 1993.

Heidrich, S., Schirmer, M., Weiss, H., Wycisk, P., Grossmann, J., and Kaschl, A.: Regionally contaminated aquifers - toxicological relevance and remediation options (Bitterfeld case study), Toxicology, 205(3), 143-155, 2004.

Hutchinson, P. A. and Webster, I. T.: Solute Uptake in Aquatic Sediments due to Current-Obstacle Interactions, J. Environ. Eng., 124(5), 419-426, 1998.

Hvorslev, M. J.: Time lag and soil permeability in groundwater observations, 1951.

Kasahara, T. and Wondzell, S. M.: Geomorphic controls on hyporheic exchange flow in mountain streams, Water Resour. Res., 39(1), 1004, doi:10.1029/2002WR001386, 2003.

Lapham, W.: Use of Temperature Profiles Beneath Streams to Determine Rates of Vertical Ground-Water and Vertical Hydraulic Conductivity, 1989.

Packman, A. I. and Bencala, K. E.: Modeling methods in the study of surface-subsurface hydrologic interactions, in: Streams and Ground Waters, edited by: Jones, J. B. and Mulholland, P. J., Academic Press, 45-80, 2000.

Saenger, N., Kitanidis, P. K., and Street, R. L.: A numerical study of surface-subsurface exchange processes at a riffle-pool pair in the Lahn River, Germany, Water Resour. Res., 41(12), w12424, doi:10.1029/2004WR003875, 2005.

Salehin, M., Packman, A., and Zaramella, M.: Hyporheic exchange with gravel beds: Basic hydrodynamic interactions and bedform-induced advective flows, J. Hydraulic EngineeringAssoc., 130(7), 647-656, 2004.

Silliman, S. E., Ramirez, J., and McCabe, R. L.: Quantifying downflow through creek sediments using temperature time series: onedimensional solution incorporating measured surface temperature, J. Hydrol., 167(1-4), 99-119, 1995.

Stallman, S.: Steady one-dimensional fluid flow in a semi-infinite porous medium with sinusoidal surface temperature, J. Geophys. Res., 70(12), 2821-2827, 1965.

Stonestrom, D. A. and Blasch, K. W.: Determining temperature and thermal properties for heat-based studies of surface-water ground-water interactions, in: Heat as a Tool for Studying the Movement of Ground Water Near Streams, edited by: Stonestrom, D. A. and Constantz, J., 73-80, 2003.

Stonestrom, D. and Constantz, J.: Heat as a Tool for Studying the 
Movement of Ground Water Near Streams, 2003.

Storey, R. G., Howard, K. W. F., and Williams, D. D.: Factors controlling riffle-scale hyporheic exchange flows and their seasonal changes in a gaining stream: A three-dimensional groundwater flow model, Water Resour. Res., 39(2), 1034, doi:10.1029/2002WR001367, 2003.

Suzuki, S.: Percolation measurements based on heat flow through soil with special reference to paddy fields, J. Geophys. Res., 65(9), 2883-2885, 1960.

Thibodeaux, L. J. and Boyle, J. D.: Bedform-Generated Convective-Transport in Bottom Sediment, Nature, 325(6102), 341-343, 1987.

Walkow, F.: Umweltreport Bitterfeld 96, Landkreis Bitterfeld. Bitterfeld, Germany, 1996.
Walkow, F.: The dioxin pollution of Bitterfeld-site description, in: Consoil 2000: Bitterfeld/Spittelwasser Site Case StudyComparison of Solutions for a Large Contamination Based on Different National Policies, Conference on Contaminated Soil 2000, Leipzig, Germany, 2000.

Woessner, W. W.: Stream and fluvial plain ground water interactions: Rescaling a hydrogeologic thought, Ground Water, 38(3), 423-429, 2000.

Wroblicky, G. J., Campana, M. E., Valett, H. M., and Dahm, C. N.: Seasonal variation in surface-subsurface water exchange and lateral hyporheic area of two stream-aquifer systems, Water Resour. Res., 34(3), 317-328, 1998. 